NBER WORKING PAPER SERIES

\title{
THE COMOVEMENT OF RETURNS AND INVESTMENT WITHIN THE MULTINATIONAL FIRM
}

\author{
Mihir A. Desai \\ C. Fritz Foley \\ Working Paper 10785 \\ http://www.nber.org/papers/w10785 \\ NATIONAL BUREAU OF ECONOMIC RESEARCH
1050 Massachusetts Avenue
Cambridge, MA 02138
September 2004
}

This paper was prepared for the 2004 NBER International Seminar on Macroeconomics in Reykjavik, Iceland. The statistical analysis of firm-level data on U.S. multinational companies was conducted at the International Investment Division, Bureau of Economic Analysis, U.S. Department of Commerce under arrangements that maintain legal confidentiality requirements. The authors thank José Campa, Fabio Canova, Richard Clarida, Jeffrey Frankel, Francesco Giavezzi, Evi Pappa, Bill Zeile, and other seminar participants for helpful comments. The views expressed are those of the authors and do not reflect official positions of the U.S. Department of Commerce. Desai thanks the Division of Research at Harvard Business School for generous financial support. The views expressed herein are those of the author(s) and not necessarily those of the National Bureau of Economic Research.

(C)2004 by Mihir A. Desai and C. Fritz Foley. All rights reserved. Short sections of text, not to exceed two paragraphs, may be quoted without explicit permission provided that full credit, including $\odot$ notice, is given to the source. 
The Comovement of Returns and Investment Within the Multinational Firm

Mihir A. Desai and C. Fritz Foley

NBER Working Paper No. 10785

September 2004

JEL No. F21, F23, F36, F42, G15

\begin{abstract}
$\underline{\text { ABSTRACT }}$
Can financial integration, particularly the cross-border investments of multinational firms, help explain the synchronization of business cycles? This paper presents evidence on the comovement of returns and investment within U.S. multinational firms to address this question. These firms constitute significant fractions of economic output and investment in most large economies, suggesting that they could create significant economic linkages. Aggregate measures of rates of return and investment rates of U.S. multinational firms located in different countries are highly correlated across countries. Firm-level regressions demonstrate that rates of return and investment rates of affiliates are highly correlated with the rates of return and investment of the affiliate's parent and other affiliates within the same parent system, controlling for country and industry factors. The evidence on these interrelationships and the importance of multinationals to local economies suggests that global firms may be an important channel for transmitting economic shocks. This evidence also sheds light on asset pricing puzzles related to the diversification benefits provided by multinational firms.
\end{abstract}

Mihir A. Desai

Graduate School of Business Administration

Harvard University

Soldiers Field

Boston, MA 02163

and NBER

mdesai@hbs.edu

C. Fritz Foley

Graduate School of Business Administration

Harvard University

Soldiers Field

Boston, MA 02163

ffoley@hbs.edu 


\section{Introduction}

To what degree do increasing levels of financial integration amongst the world's major economies lead to changes in the synchronization of business cycles? In particular, what role could the dramatic increases in foreign direct investment play in explaining the comovement of aggregate measures of economic activity? This paper sheds light on these questions by providing facts about the scope of foreign direct investment in different countries and the correlations in investment and returns of distinct U.S. multinational operations around the world.

The relevance of a world factor in explaining movements in economic aggregates appears to be uncontroversial. What is less well understood is what factors might account for the high degrees of correlation in macroeconomic variables. High levels of financial and trade integration, as pointed out by Frankel and Rose (1998) and Heathcote and Perri (2002), can theoretically lead to either increasingly idiosyncratic or correlated movements in economic aggregates. The link between financial and trade integration and the synchronization of business cycles remains an open question, with somewhat contradictory evidence emerging from econometric analysis of aggregate data.

Rather than filter the economy-wide data in a distinctive way, we approach this question with micro data on the behavior of U.S. multinational companies (MNCs) and emphasize the role that linkages within these firms may play in creating global linkages. In order to explore this channel, we pose a series of questions about the patterns of U.S. multinational activity around the world. First, are the activities of multinational firms sufficiently important to local economies to create these linkages? Second, is there any evidence that aggregate measures of multinational activity comove in a manner that is distinctive from the behavior of local firms around the world? Finally, is there evidence that activities of U.S. multinationals in the U.S. or in other host countries help explain affiliate investment plans and rates of returns after controlling for conditions in the affiliate host country and industry? Put differently, is multinational affiliate performance around the world a function of parent shocks or shocks affecting other affiliates within the same firm after controlling for national, industry and world factors? 
The analysis makes use of measures of the gross product, or value added, of multinational activity and micro data that capture the inner workings of multinational firms. The Bureau of Economic Analysis (BEA) provides national income accounting analogs for the activities of U.S. multinationals around the world. These allow for the comparison of economic output by multinational firms and the size of the local economy. Additionally, these data allow for the calculation of rates of return that are a staple of macroeconomic analysis, as in Poterba (1998). Affiliate-level data on investment and returns are employed to determine the degree to which returns and investments by multinational affiliates around the world comove with returns and investments of the same firm outside of the host country controlling for local returns and investment rates.

The results indicate that U.S. multinationals constitute a significant fraction of output and investment for many major economies and their significance has grown over the last two decades. Averaged across the G-6 countries, U.S. multinational affiliates alone comprised more than four percent of output and capital expenditures in their host countries in 1999 with levels as high as ten percent in several countries. ${ }^{1}$ These ratios indicate the potential for multinationals to act as a channel of economic shocks. A descriptive look at the correlation coefficients of rates of return for multinational activity across countries indicates that such correlations are high and in most cases exceed correlations of returns based on economy wide measures. Similar patterns exist for correlations of rates of investment of multinational firms relative to local economy aggregates.

These high correlations of country-wide returns and investment within multinational firms suggest that shocks that occur in one part of the world may be transmitted across borders as a consequence of a multinational firm's worldwide network of subsidiaries. In order to test this more rigorously, affiliate-level regressions attempt to identify how affiliate returns comove with local firm returns, the returns of other foreign affiliates of the same parent, and the returns on U.S. operations of the affiliate's parents. Both within-MNC measures of returns - the returns on U.S. operations and returns on

\footnotetext{
${ }^{1}$ Throughout the paper, we refer to the G-6 countries to indicate the G-7 (G-8) after excluding the United States (the United States and Russia). G-6 countries include Canada, France, Germany, Italy, Japan, and the United Kingdom.
} 
other foreign operations of the parent - are significant in explaining the return of affiliates controlling for local returns. In a similar vein, parent and other foreign affiliate investment rates retain explanatory power in explaining affiliate investment rates after controlling for local economy investment rates. These results are robust to the inclusion of country/year and industry/year fixed effects that control for the country and industry shocks that have been emphasized in the macroeconomics literature, as in Stockman (1988) and Glick and Rogoff (1995). These results hold for the overall sample of affiliates and the sample of affiliates in G6 countries. These results suggest that the economic linkages created by intrafirm dynamics, emphasized by Peek and Rosengren (1997, 2000) for the case of Japanese bank lending and California real estate activity, may be considerably more widespread.

While the various fixed effects employed in the analysis control for a variety of alternative explanations, it is possible that the results reflect an important industry with its own dynamics, the petroleum industry, or linkages created by intrafirm trade. In order to consider these alternatives, further regression analysis tests if observed correlations differ for affiliates in manufacturing relative to non-manufacturing and for affiliates that serve the local market relative to exporting affiliates. Robustness checks indicate that the dynamics of the petroleum industry are not driving the results, that the patterns hold for manufacturing affiliates, and that results are similar for affiliates that do and do not sell goods outside of their host country.

Taken together, the evidence provided in the paper suggests that the scope and dynamics of multinational firm activity are consistent with these firms serving as a meaningful channel for the transmission of economic shocks. Investment and returns are linked across parts of the same firm located in different countries, and these linkages cannot be explained by patterns in aggregate investment and returns at the country or industry level. This analysis raises several questions for future research. What aspects of firm internal markets - internal capital markets, transfers of technology - might create these linkages? How much of these linkages can be explained by shocks to input costs faced by multinationals or by international rent sharing by workers across borders within multinationals? To what degree are multinational firms contributing to the synchronization of business cycles relative to trade linkages and bank lending and other 
factors? Given the exploratory nature of the analysis in this paper, we believe the results suggest that further work on how multinational firms create global economic linkages is merited.

The rest of the paper is organized as follows. The second section describes the related literature on international business cycles and the internal capital markets of firms and outlines the empirical methodology. The third section provides an overview of the growth of U.S. multinational activity, the changing industrial composition of investment, the relative importance of U.S. multinational activity to local economies around the world, and the changing geographic concentration of U.S. multinational activity. The fourth section provides evidence on the correlation of returns and investment rates to understand the economic linkages created by multinational firms. The fifth section discusses results from the firm-level regressions and the sixth section provides robustness checks for the basic results. A concluding section suggests extensions of this work.

\section{2. $\quad$ Related Literature and Empirical Methodology}

This investigation of the correlation of returns and investment plans within multinational firms is related to the growing literature on the synchronization of business cycles and asset returns and some recent literature on multinational and multidivision firms that points out potential sources of synchronicity with firms.

\subsection{International Business Cycles}

Studies of the synchronization of business cycles typically rely on econometric tests employing macroeconomic aggregates, as in Baxter and Stockman (1989), Backus, Kehoe and Kydland (1992, 1995), Doyle and Faust (2002), Kose, Otrock and Whiteman (2003), and Stock and Watson (2003). These studies typically find evidence of a world factor in dictating output variability with somewhat contradictory results on the trend in degrees of comovement amongst major economies. Heathcote and Perri (2002) find reduced correlations in output and tie these reduced correlations to increased financial integration. Brodo and Helbling (2003) suggest that synchronization levels have increased over a longer historical period and across a variety of exchange rate regimes. These studies typically conclude, as in Kose, Otrok and Whiteman (2003) and Stock and Watson (2003), with calls for further investigation of the sources, rather than the degree, 
of these global correlations. One such investigation of the sources of these correlations is provided by Frankel and Rose (1998) who provide evidence of a correlation between trade linkages and output correlations. ${ }^{2}$

Linkages between economic aggregates can be particularly trenchant in an emerging market setting where output fluctuations can be large and appear, to some observers, to be contagious. Examinations of these linkages of output and stock market movements in emerging markets have emphasized trade linkages (as in Eichengreen and Rose (1999)), financial flows (as in Kaminsky, Lyons and Schmukler (2001)), or combinations of these factors. ${ }^{3}$ Studies of the comovement of returns in emerging markets are part of the larger literature on the degree to which stock markets comove (pioneered in King and Wadhwani (1990) and surveyed recently in Goetzmann, Li and Rouwenhorst (2002)) and if assets are priced locally or globally, as reviewed in Karolyi and Stulz (2002).

As detailed below, the considerable scope of multinational activity around the world suggests that multinational firms may be a channel for the transmission of economic shocks around the world. There is limited evidence on this channel with contradictory conclusions. Forbes and Chinn (2003) indicate that bilateral FDI flows do not explain global linkages in financial markets while Jansen and Stokman (2004) indicated that international business cycle comovements are more pronounced for countries with large amounts of bilateral foreign direct investment flows. An investigation of the degree to which returns and investment plans comove within firms using micro data affords the opportunity to isolate more precisely the scope of this transmission channel. Such an examination also affords the opportunity to incorporate a rich set of industry and country controls given the interest in the literature, as in Stockman (1988) and Glick and Rogoff (1995), in the relative importance of industry and country specific shocks factors in explaining investment and current account behavior.

\subsection{The Internal Linkages of Multinational and Multidivisional Firms}

\footnotetext{
${ }^{2}$ See Canova and Marrinan (1998), Canova and de Nicoló (2003) and Lumsdaine and Prasad (2003) for alternative econometric techniques for identifying common components to business cycles and their sources using aggregate data.

${ }^{3}$ See the papers collected in Claessens and Forbes (2001).
} 
The literature of the internal markets of firms indicates some potential reasons for why returns and investment comove within a firm. Finance scholars have recently turned their attention to the efficiency of the allocation of capital within firms. ${ }^{4}$ Both Rajan, Servaes and Zingales (2000) and Scharfstein and Stein (2000) propose rationales for how investment becomes "socialized" through a multi-divisional enterprise leading to inefficient allocation of capital within conglomerates. Such a socialization of investment or cross-subsidization would appear as correlated investment and performance across countries in a multinational setting. In the multinational setting, firms appear to use internal capital market opportunistically to overcome local rigidities - including costly external finance and capital controls - as in Desai, Foley and Hines (2003a, 2004). Given that these internal capital markets appear to be so active, it is conceivable that shocks to geographically disparate operations could be transmitted around the world through multinationals.

Underlying trends in the patterns of real activity by multinationals might also give rise to global linkages. As described by Feenstra (1995), production processes within these firms have increasingly become fragmented around the world. As a consequence, multinational activity within these economies is more likely to be tied to non-local factors providing another channel for the transmission of shocks and the comovement of returns within firms. Desai, Foley and Hines (2003b) demonstrate how these patterns of the internalization of activity have also changed the ownership preferences of multinational firms.

It is also possible that changes in input costs for multinationals give rise to comovement of returns and investment within firms. Budd, Konings, and Slaughter (2002) consider the process by which wages are set within multinationals and raise the possibility that this process affects the transmission of shocks across borders. This work finds evidence that wages in one location depend on the performance of the firm in other locations. Therefore, international rent sharing across workers of multinational firms might also induce the comovement of returns within firms.

\footnotetext{
${ }^{4}$ See Stein (2003) for a survey of this literature.
} 
There has been limited empirical evidence on the interrelationship of investment plans within firms that span national boundaries. Peek and Rosengren $(1997,2000)$ find that Japanese bank lending decisions in California reflect changes in the value of their Japanese loan portfolios and that these changed lending decisions had real consequences. More widespread evidence of linkages created by multinational firms has not been provided. The one exception to this that we know of is the study by Stevens and Lipsey (1992) of seven multinational firms over twenty years. This study, despite its limited sample, finds evidence of significant interdependence in investment plans between foreign and domestic operations. If, indeed, investment plans and returns are highly correlated around the world within a multinational firm, this may help explain why investors place a limited value on mutlinationality, as examined in Errunza and Senbet (1984) and Morck and Yeung (1991), or even a discount on global diversification as in Denis, Denis and Yost (2002).

\subsection{Data and Empirical Methodology}

In order to isolate the scope and dynamics of U.S. multinational activity, we employ detailed data collected by the U.S government. We use the 1982 through 1999 results of the Bureau of Economic Analysis (BEA) annual survey of U.S. Direct Investment Abroad to create a panel of data on the gross product, returns, and investment of U.S. multinational affiliates and parents. These surveys ask reporters to file detailed survey forms for each affiliate, as well as information on the domestic activities of U.S. parents. The International Investment and Trade in Services Survey Act governs the collection of the data. The Act ensures that "use of an individual company's data for tax, investigative, or regulatory purposes is prohibited.” Willful noncompliance with the Act can result in penalties of up to $\$ 10,000$ or a prison term of one year. As a result of these assurances and penalties, BEA believes that coverage is close to complete and levels of accuracy are high.

U.S. direct investment abroad is defined as the direct or indirect ownership or control by a single U.S. legal entity of at least ten percent of the voting securities of an incorporated foreign business enterprise, or the equivalent interest in an unincorporated 
foreign business enterprise. ${ }^{5}$ The survey forms that U.S. multinational firms are required to complete vary depending on the year and the size of the entity surveyed. Although the most extensive data are available for 1982, 1989, 1994 and 1999, when BEA conducted Benchmark Surveys, we use data from the intervening years as well. ${ }^{6}$ Since many of the variables of interest are not collected for minority owned affiliates, we restrict our sample to include affiliates in which the combined direct and indirect ownership claim by a U.S. parent exceeds 50 percent. BEA collects identifiers linking affiliates through time, thereby permitting the creation of a panel. ${ }^{7}$

The BEA data include national income accounting analogs for the activities of multinational affiliates in countries around the world. Affiliate gross product, a measure of value-added that is computed by BEA from data reported in the survey, was developed in order to measure the extent of multinational activities in a way that is free from double counting, unlike sales data that reflect value-added within an affiliate and the value of intermediate inputs purchased by an affiliate. As in national income accounting, this measure is decomposed into employee compensation, profit-type return (a measure of profits from current production), net interest paid, indirect business taxes, and a capital consumption allowance.

The analysis that follows begins by employing the BEA measure of gross product in order to characterize the distribution of U.S. multinational firms across countries and industries. Values of aggregate affiliate data within a host country are compared to host country GDP, as measured by the World Bank (2003), to indicate the prevalence of multinational activity. We also compute measures of the importance of affiliate investment in host countries by scaling aggregate affiliate investment by gross fixed capital formation, taken from the World Bank (2003).

In order to consider the comovement of returns of the aggregate activities of U.S. multinationals in distinct host countries, we employ a variety of measures. Using the

\footnotetext{
${ }^{5}$ In order to be considered as a legitimate foreign affiliate, the foreign business enterprise should be paying foreign income taxes, have a substantial physical presence abroad, have separate financial records, and should take title to the goods it sells and receive revenue from the sale. In order to determine ownership stakes in the presence of indirect ownership, BEA determines the percentage of parent ownership at each link and then multiplies these percentages to compute the parent's total effective ownership.

${ }^{6}$ In non-benchmark years, reporting exemption levels were higher and less information is collected.

${ }^{7}$ For a detailed description of the BEA data, see Mataloni (1995).
} 
gross product data, we define the rate of return as the ratio of the sum of the profit-type return, net interest paid, indirect business taxes and the capital consumption allowance to total assets. We also employ two financial accounting based measures of returns; return on equity is the ratio of net income to owners' equity and return on assets is the ratio of net income to assets. In order to compute correlations in economy wide returns, we rely on data in Poterba (1998) and data from Ken French's website for information on rates of return and return on equity. ${ }^{8}$ The Ken French data cover a large sample of publicly traded firms and include information on the dollar stock return in local markets also. In studying the comovement of investment, we analyze correlations of aggregate affiliate capital expenditures across countries as well as these expenditures scaled by aggregate affiliate gross product and affiliate assets. Economy wide investment is measured as the value of gross fixed capital formation, and we analyze correlations of this measure and this measure scaled by GDP.

In order to analyze the comovement of returns and investment within the firm more rigorously, we employ a specification where the dependent variable is a measure of returns or investment at the affiliate-year level. In order to trace through effects of a multinational parent's activity elsewhere in the world, we include independent variables that measure returns or investment for the affiliate's parent in the U.S. (referred to as parent returns or parent investment) and the returns or investment of other affiliates of the parent operating abroad (referred to as other affiliate returns or other affiliate investment). Finally, measures of local firm activity are also included as explanatory variables as are varying combinations of affiliate, year, and country/year and industry/year fixed effects in order to ensure that these within-firm measures are not reflecting omitted factors. All standard errors are clustered at the firm level to correct for serial correlation.

\section{The Distribution of Multinational Activity, 1982-1999}

In order to consider the scope and nature of U.S. multinational activity, Table 1 provides some sense of where multinationals have historically been most active, by

\footnotetext{
${ }^{8}$ The Ken French data can be found at http://mba.tuck.dartmouth.edu/pages/faculty/ken.french/data_library.html.
} 
country, and how this compares with the share of non-U.S. economic output that these countries constitute. These figures are presented for the four benchmark years and are limited to those countries where either the country's share in worldwide output or the country’s share of U.S. multinational output was at least one percent in 1999.

Several patterns emerge from this table. First, U.S. multinational activity is more concentrated than global output. By 1999, these twenty three countries constitute 83\% of non-U.S. output and 88\% of U.S. multinational activity. This level of concentration has also increased quite markedly over the last two decades. Second, it is useful to consider those countries for which the two measures of the distribution of activity differ by large margins. Here, several large discrepancies are apparent. The United Kingdom, Canada, Australia, and Ireland stand out as countries with disproportionately large shares of U.S. multinational activity. In contrast, many countries in Asia - most notably Japan - feature uncharacteristically low levels of U.S. multinational activity. Finally, several large emerging markets - particularly China and India - that have received large amounts of attention for their inward foreign direct investment still have relatively little U.S. multinational activity given their share of world output, despite recent sharp accelerations. It is reassuring that these figure are relatively well-behaved over time and conform, largely, to the folklore on U.S. multinational activity as being concentrated in developed countries, as having a bias toward Anglo countries, and as being of limited scope in Japan. It is also worth noting that if multinationals did play a significant role in driving international business cycles, the distribution of U.S. multinational activity would help explain the patterns presented in Stock and Watson (2003) of an Anglo block of correlated economies and the distinct dynamic of the Japan economy.

In order to consider the possibility that multinational firms serve as channel of economic shocks, it is useful to isolate the relative contribution of U.S. multinationals to local output or investment. Table 2 presents the ratio of U.S. MNC gross product and investment to economy wide measures, by country. The first column presents the average ratio of affiliate gross product to host country GDP over the 1982 to 1999 period, and the second column presents this ratio for 1999. The third and fourth column present ratios of affiliate capital expenditures to gross fixed capital formation averaged over the sample period and for 1999. These ratios are crude measures of the relative importance 
of multinational activity for local economies. They are crude in several respects. First, they only represent U.S. multinational activity and, as such, understate the scope of overall multinational activity. Second, measures of economy-wide activity in the denominators include government activity, and, therefore, the ratios understate the relative importance of multinational firms to the private sector in these countries.

Table 2 reveals several salient facts about the relative importance of U.S. multinational activity. First, a comparison of the averages from 1982 to 1999 and in 1999 indicates that the relative importance of U.S. multinational activity has increased in almost all of the countries in the table. Second, the increases in the relative importance of multinationals are most pronounced in Asia, though multinationals maintain a more significant presence in Europe than in Asia. Third, the U.S. multinational shares of total output and investment vary considerably but are seldom trivial and are often quite large. For Ireland, the United Kingdom, and Canada, these shares are close to or above ten percent. Most multinational shares are in the single digits, which given the measurement issues mentioned above, seems a significant enough channel to create global linkages.

Finally, it is useful to consider the industrial dispersion of U.S. multinational activity. The share of multinational gross product, by industry is provided in Figure 1. Unsurprisingly, the share of petroleum, which is separated from manufacturing in the BEA data and includes extraction, refining, service, and wholesale trade activities related to oil and gas, has dropped precipitously over the period from 1982 to 1999 as shares of several sectors - notably, services and finance-related industries - have increased. Given the distinct dynamics that are potentially associated with the petroleum industry, the correlations of returns and investment presented below are considered separately for manufacturing industries.

\section{The Correlations of Returns and Investment Inside Multinational Firms}

We begin by presenting some raw correlations of returns and investment rates of affiliates across countries and compare these correlations to correlations of economy wide measures across countries. These correlation tables are obviously only suggestive since the time series data on U.S. multinational activity only cover the 1982 to 1999 period. Descriptive statistics for the sample employed in the correlation tables and the 
regression tables are presented in Table 3. Tables 4 and 5 present the correlations across G-6 countries.

The top panel of Table 4 provides correlations of our three measures of returns to affiliate activity; these measures are the rate of return (ROR), the return on equity (ROE), and the return on assets (ROA). All of these correlations are positive, and all but five of them differ from zero by statistically significant margins. Correlations of rates of return are the largest, ranging from 0.87 to 0.97 . There is more variation in the correlations of ROE and ROA than ROR. Part of this variation may result from shortcomings of these measures in capturing returns to capital. Net income and owners' equity reflect only a component of returns and a component of capital. They also reflect the capital structure choice of affiliates, a choice that is likely to vary through time within countries and one that may be guided by a variety of tax and managerial considerations.

The bottom panel of Table 4 presents similar correlations using economy wide measures of returns. The ROR correlations are all smaller than the ROR correlations observed for multinational firms. The Ken French data do not cover Canada, but for the other countries, economy wide correlations of ROE are smaller than affiliate correlations for all but two country pairs. It is not possible to directly compare correlations of stock returns to any measure of affiliate returns since most affiliates are not publicly traded, but these correlations also are smaller that the correlations of affiliate rates of return, and they are of a similar magnitude as the correlations of affiliate ROE. If attention is restricted to multinational affiliates in manufacturing, in order to put aside concerns that common shocks to the petroleum industry are driving our results, the results are largely the same.

Table 5 shows correlations of measures of investment across countries. The top panel presents correlations computed from three measures of affiliate investment activity: the level of capital expenditures, capital expenditures scaled by gross product, and capital expenditures scaled by assets. All but one of these correlations is positive and more than three-fourths of the presented correlations are positive and statistically significant. The correlations of levels of capital expenditures appear to be the highest. Since capital expenditures are measured in nominal terms, these correlations could reflect correlations in inflation rates. The other two measures are not subject to this potential shortcoming. 
The bottom panel of Table 5 displays correlations of two economy wide measures of investment. Capital expenditures are measured using data on gross fixed capital formation, and the correlations cover levels of capital expenditures and capital expenditures scaled by GDP. Although the correlations of country wide measures of investment exceed correlations of affiliate measures of investment in just over half of the comparable cases, both sets of correlations are of a similar magnitude for most country pairs. As with the correlations of returns, restricting attention to manufacturing affiliates does not materially change these results. Taken together, the evidence in Tables 4 and 5 indicates that returns and investment are correlated within U.S. multinational firms. In many cases, the correlations of these measures of activity within firms exceed correlations of these measures for the broader economy. In order to study the correlates of affiliate returns more carefully, we now turn to regression analysis that permits for a richer set of controls for other confounding factors.

\section{Firm Level Regressions}

The specification outlined in section 2.3 provides a method for further analyzing the degree to which the correlations of aggregate returns and investment represent withinfirm dynamics. Table 6 presents firm-level evidence on the correlation of returns inside multinational firms. In order to facilitate comparison of returns across the different parts of a multinational firm, we consider the accounting based measure of return on equity and employ the Ken French data to control for local firm returns on equity. Observations are at the affiliate-year level, and the dependent variable is the return on equity, calculated as the ratio of net income to owner's equity. The specifications in columns 1-6 employs affiliate fixed effects to control for unobserved heterogeneity across affiliates and year fixed effects to capture movements in a world factor that might explain the comovement of returns. It is worth noting that these year fixed effects also control for a wide variety of global shocks like oil price changes that would potentially drive a world factor.

In the simple specification in column 1 , the coefficient on parent return on equity indicates that an affiliate's parent domestic return helps explain movements in affiliate returns in a statistically significant manner. Column 2 considers the role of the return on 
the activities of the other foreign affiliates within a parent system by including this return as an additional explanatory variable. In this specification the sample size is reduced as affiliates that are the only foreign affiliate in a parent system are dropped. The coefficient on the parent's domestic activity is slightly smaller but remains significant, and the 0.14 coefficient on the parent's other foreign activity is positive and highly significant. Of course, these coefficients might represent the underlying correlation of country level returns across countries in which a parent is active. In order to address this concern, the specification in column 3 includes the affiliate's host country return on equity. Given the limited coverage of the French ROE data, the sample is reduced quite dramatically. In this specification, the local return is not significant, and the coefficients on the parent's domestic and foreign activities remain largely unchanged.

Given the prevalence of affiliate activity in G-6 countries, the high level of interest in the transmissions of shocks among these countries, and the availability of data within these countries, it useful to run the specification presented in columns 1-3 in just this setting. The results are largely similar with parent domestic and foreign returns explaining affiliate returns and local returns having a positive but insignificant sign. Coefficients on parent ROE and other affiliate ROE are very similar to previous specifications reflecting the importance of G-6 activity to the overall sample and suggesting that these factors have a similar relationship to affiliate ROE both inside and outside the G-6.

Within the context of the G-6, it is possible to impose even further controls to account for the dynamics of local economies and affiliate industries. Specifically, the specification in column 7 employs country/year and industry/year fixed effects. ${ }^{9}$ The country/year fixed effects control for a variety of shocks that have similar effects across firms within a country including changes in interest rates, supply or demand shocks, and policy changes. These fixed effects also control for time varying factors that are specific to US/host country country pairs, and therefore they rule out interpretations of the parent return variable related to such factors. For example, any common variation in affiliate returns or U.S. parent returns driven by changes in the host country currency to U.S.

\footnotetext{
${ }^{9}$ Computational constraints limit the use of these fixed effects in the full sample.
} 
dollar exchange rate is absorbed by the country/year fixed effects and cannot explain the results. Since the specification also includes industry/year fixed effects, identification comes from variation within industries so shocks to specific sectors are also implicitly controlled for. In the specification in column 7, the coefficients on parent domestic and foreign returns are similar to their level in previous specifications and retain their statistical significance. Across all of the specifications, the domestic and foreign withinMNC returns help explain an affiliate's returns after controlling for various measures of local returns.

Table 7 employs a similar empirical framework to investigate the interrelationship of investment within the multinational firm. In columns 1 through 7 the dependent variable is the log of affiliate capital expenditures, and all specifications employ affiliate and year fixed effects. As with returns, the coefficient on parent domestic investment in column 1 is positive and highly significant. When the additional independent variable of other affiliate investment is included in column 2, the coefficient on parent domestic investment is reduced in magnitude but retains its statistical significance. Other affiliate investment is also highly significant and the relevance of parent domestic and foreign activities for affiliate investment mirrors the results in Table 5. In column 3, the additional control for local investment is highly significant but does not materially change the coefficients or significance levels of the within-parent variables. When attention is restricted to the G-6 in columns 4 through 7, the results are qualitatively similar with parent domestic and foreign activities helping to explain affiliate investments after controlling for local investment rates. As in Table 6, column 7 of this table includes country/year and industry/year fixed effects to pick up country or industry specific factors that might drive affiliate investment. Parent domestic investment and investment by parent affiliates in other host countries remain positive and significant in explaining affiliate investment.

The evidence provided on the correlates of affiliate investment might be affected by changes in firm scope related to merger activity or spin off activity. In order to address this concern, we repeat the analysis in Table 7 using scaled measures of investment activity. The results of this analysis appear in columns 8 through 14 of Table 7. The results are qualitatively similar to those in columns 1 through 7 . Both parent 
domestic investment and investment by other affiliates of a parent are significantly correlated with affiliate investment. The magnitude of the coefficients on these variables is similar for the full sample and for G-6 countries, and these results are robust to controlling for country and industry factors.

\section{Robustness Checks}

The results in Tables 6 and 7 may reflect the dynamics of a particular industry (particularly petroleum) or the fact that some affiliates selling large fractions of their output to outside of their host country. The analysis in Table 8 considers these two possible explanations using specifications similar to those already examined. Although the results in Tables 6 and 7 are similar for specifications that do and do not include industry/year fixed effects, it could be the case that the results are driven by patterns in particularly important sectors such as petroleum. For example, oil price shocks might have effects that differ across firms but are similar within firms in the petroleum sector. To address this possibility, we allow estimates of the correlations of affiliate returns and investment with returns and investment of other parts of the same firm to vary for affiliates within and outside of manufacturing since all petroleum related industries are classified outside of manufacturing in the BEA data. We do this by classifying affiliates into manufacturing and non-manufacturing affiliates and including interactions of a dummy equal to one for affiliates outside of manufacturing and measures of parent and other affiliate returns in the basic specifications provided in Table $6 .^{10}$

The specification presented in columns 1 of Table 8 is similar to the specifications of Table 6 but includes the additional interaction terms with the non-manufacturing dummy. The 0.063 coefficient on parent ROE indicates that the returns of affiliates in manufacturing are significantly correlated with parent returns, and the 0.007 coefficient on parent ROE interacted with the non-manufacturing dummy indicates that this correlation is statistically indistinguishable for non-manufacturing affiliates. The same pattern holds for the coefficient on other affiliate ROE. Similar results are also obtained

\footnotetext{
${ }^{10}$ The specifications in Table 8 also include controls for local market ROE and investment and their interactions with either the non-manufacturing dummy or local sales dummy. These coefficients are not reported in order to emphasize the relative effect of industry and sales destination on the primary coefficients of interest.
} 
in the specification presented in column 3 which includes country/year and industry/year fixed effects and is restricted to the G-6 sample. The specifications in columns 5 and 7 of Table 8 are similar to those from columns 8 through 12 of Table 7 and illustrate that the correlations of investment within the multinational firm are also not distinctive for manufacturing affiliates. It does not appear that peculiarities of a single dominant sector can explain the interrelationships of returns and investment within multinational firms.

Another potential explanation of the results in Table 6 and Table 7 is that they represent the effect of trade linkages within multinational firms. While it is not possible to isolate the extent to which affiliates buy inputs from abroad, it is possible to consider if within-firm correlations of returns and investment depend on the degree to which affiliates sell output locally or outside of their host country. To do this, we create a dummy that is equal to one for affiliates that sell all of their output in their host country in all years they appear in the sample, and we interact this dummy with parent returns and other affiliate returns and include these interactions in specifications similar to those presented in Table 6.

The results of these specifications appear in columns 2 and 4 of Table 8. In column 2, the coefficient on parent ROE indicates that parent returns and affiliate returns of affiliates that sell some output abroad are positively correlated, and the small and insignificant coefficient on parent ROE interacted with the local sales focus dummy illustrates that this correlation is no different for affiliates that are purely focused on serving the domestic market. The returns of locally focused affiliates and affiliates that sell goods abroad also exhibit similar correlations with the returns of other affiliates. These results are similar in the specification in column 4, which includes country/year and industry/year fixed effects and is restricted to G-6 countries. The correlations of affiliate capital expenditures and parent capital expenditures and the correlations of affiliate capital expenditures and other affiliate capital expenditures are also no different for affiliates that are focused on the local market and those that sell outside of their host country, as the regressions presented in columns 6 and 8 of Table 8 demonstrate. This evidence suggests that observed interrelationships of returns and investment within multinationals are not driven by the outward orientation of affiliate sales. 


\section{Conclusion}

U.S. multinationals comprise significant fractions of output and investment in much of the world. Their rates of return and investment levels are more highly correlated around the world than many similar measures for local firms. Controlling for local returns and investment levels, a multinational parent's domestic and foreign operations are highly correlated with an affiliates returns and investment levels. Although the results do not discriminate among all the channels through which multinationals could affect the transmission of economic shocks, they do indicate that interrelationship within multinational firms are not solely driven by affiliates outside of manufacturing or by affiliates that play a role in a worldwide production process and sell goods outside of their host country.

These results generate a number of additional questions. Given the high degree of interdependence in returns across countries for multinational firms, is it fair to view them as an asset class that provides exposure to foreign markets? If, indeed, investment plans and returns are highly correlated around the world within a multinational firm, this may help explain why investors place a limited value on mutlinationality, as examined in Errunza and Senbet (1984) and Morck and Yeung (1991). What characteristics of multinational firms - their internal capital markets, their intrafirm trade, their ability to explore intangible property in several locations - are driving these linkages in returns and investments? If these linkages are so significant, how should firms consider capital budgeting when they allocate capital around the world?

Similarly, these facts prompt questions related to the nature of economic linkages. To what degree is the emergence of an Anglo business cycle and the distinct dynamic of Japan, as in Stock and Watson (2003), a reflection of the nature of FDI flows between those countries? What exogenous shocks might usefully be employed to better identify the relevance of multinational firms for transmitting shocks? How can macroeconomic models used to decompose the sources of global correlations incorporate the activities of multinational firms? If financial integration through foreign direct investment is associated with such highly correlated investments and returns, what are the welfare consequences of such integration? We leave these questions for future research. 


\section{References}

Backus, David K., Patrick J. Kehoe and Finn E. Kydland (1992). "International Real Business Cycles.” Journal of Political Economy 100:4, 745-775.

Backus, David K., Patrick J. Kehoe and Finn E. Kydland (1995). "International Business Cycles: Theory and Evidence.” In Charles Plosser, ed., Frontiers of Business Cycle Research (Princeton: Princeton University Press), 331-357.

Baxter, Marianne and Alan Stockman (1989). "Business Cycles and the Exchange Rate Regime: Some International Evidence,” Journal of Monetary Economics, 23:377-400.

Bordo, Michael D. and Thomas Helbling (2003). "Have National Business Cycles Become More Synchronized?” NBER Working Paper No. 10130.

Budd, John W., Jozef Konings and Matthew J. Slaughter (2002). "International Rent Sharing in Multinational Firms.” NBER Working Paper No. 8809.

Canova, Fabio and Jane Marrinan (1998). "Sources and Propagation of International Output Cycles: Common Shocks or Transmission?” Journal of International Economics, 46:133-166.

Canova, Fabio and Gianni de Nicoló (2003). “On the Sources of Business Cycles in the G-7” Journal of International Economics, 57:77-100.

Claessens, Stijn and Kristin J. Forbes, eds. (2001). International Financial Contagion (Boston: Kluwer Academic Publishers).

Denis, David J., Diane K. Denis and Keven Yost (2002). “Global Diversification, Industrial Diversification, and Firm Value.” Journal of Finance, 57:1951-1979.

Desai, Mihir A., C. Fritz Foley and James R. Hines Jr. (2003a). “A Multinational Perspective on Capital Structure Choice and Internal Capital Markets.” Journal of Finance, forthcoming.

Desai, Mihir A., C. Fritz Foley and James R. Hines Jr. (2003b). “The Costs of Shared Ownership: Evidence from International Joint Ventures.” Journal of Financial Economics, forthcoming.

Desai, Mihir A., C. Fritz Foley and James R. Hines Jr. (2004). “Capital Controls, Liberalizations, and Foreign Direct Investment.” NBER Working Paper No. 10337.

Doyle, Brian and Jon Faust (2002). "An Investigation of Co-movements among the Growth Rates of the G-7 Countries.” Federal Reserve Bulletin, October, 427-437.

Eichengreen, Barry and Andrew Rose (1999). "Contagious Currency Crises: Channels of Conveyance." in Takatoshi Ito and Anne Krueger, eds., Changes in Exchange Rates in RapidlyDeveloping Countries: Theory, Practice, and Policy Issues. Chicago: University of Chicago Press, 29-50.

Errunza, Vihang R. and Lemma W. Senbet (1984). "International Corporate Diversification, Market Valuation, and Size-Adjusted Evidence.” Journal of Finance 39:3, 727-743.

Feenstra, Robert C. (1998). "Integration of Trade and Disintegration of Production in the Global Economy." Journal of Economic Perspectives 12:4, 31-50. 
Forbes, Kristin J. and Menzie D. Chinn (2003). “A Decomposition of Global Linkages in Financial Markets Over Time.” NBER Working Paper No. 9555.

Frankel, Jeffrey and Andrew Rose (1998). “The Endogeneity of the Optimum Currency Area Criteria.” The Economic Journal 108:449, 1009-1025.

Glick, Reuven and Kenneth Rogoff (1995). "Global and Country-Specific Productivity Shocks and the Current Account", Journal of Monetary Economics, 35:159-192.

Goetzmann, William N., Lingfeng Li and K. Geert Rouwenhorst (2001). “Long-term Global Stock Market Correlations.” NBER Working Paper No. 8612.

Heathcote, Jonathan and Fabrizio Perri (2002). "Financial Globalization and Real Regionalization.” NBER Working Paper No. 9292.

Jansen, W. Jos and Ad C. J. Stokman (2004). "Foreign Direct Investment and International Business Cycle Comovement.” De Nederlandsche Bank Working Paper.

Kaminsky, Graciela, Richard Lyons, and Sergio Schmukler (2001). "Mutual Fund Investment in Emerging Markets: An Overview.” In Stijn Claessens and Kristin Forbes, eds., International Financial Contagion (Boston: Kluwer Academic Publishers), 158-185.

Karolyi, G. Andrew and René M. Stulz (2002). “Are Financial Assets Priced Locally or Globally?” Forthcoming in George Constantinides, Milton Harris, and René M. Stulz, eds., Handbook of the Economics of Finance (Amsterdam: North-Holland).

King, Mervyn and Sushil Wadhwani. (1990). "Transmission of Volatility between Stock Markets.” Review of Financial Studies 3:1, 5-33.

Kose, M. Ayhan, Christopher Otrok, and Charles H. Whiteman (2003). "International Business Cycles: World, Region, and Country-Specific Factors.” American Economic Review 93:4, 1216-1239.

Lumsdaine, Robin L. and Eswar S. Prasad (2003). "Identifying the Common Component in International Economic Fluctuations: A New Approach,” Economic Journal, 113:101-127.

Mataloni, Raymond J. (1997). "Real Gross Product of U.S. Companies’ Majority-Owned Foreign Affiliates in Manufacturing.” Survey of Current Business, April, 8-17.

Morck, Randall and Bernard Yeung (1991). "Why Investors Value Multinationality.” Journal of Business 64:2, 165-187.

Peek, Joe, and Eric Rosengreen (1997). "The International Transmission of Financial Shocks: The Case of Japan.” American Economic Review 87:4, 495-505.

Peek, Joe, and Eric Rosengreen (2000). "Collateral Damage: Effects of the Japanese Bank Crisis on Real Activity in the United States.” American Economic Review 90:1, 30-45.

Poterba, James M. (1998). "The Rate of Return to Corporate Capital and Factor Shares: New Estimates Using Revised National Income Accounts and Capital Stock Data.” Carnegie-Rochester Conference on Public Policy 48, 211-246. 
Rajan, Raghuran, Henri Servaes and Luigi Zingales (2000). "The Cost of Diversity: The Diversification Discount and Inefficient Investment.” Journal of Finance 55:1, 35-80.

Scharfstein, David S. and Jeremy C. Stein (2000). “The Dark Side of Internal Capital Markets: Divisional Rent-Seeking and Inefficient Investment.” Journal of Finance 55:6, 2537-64.

Stein, Jeremy (2003). “Agency, Information and Corporate Investment.” In George Constantinides, Milt Harris and Rene Stulz eds., Handbook of the Economics of Finance (New York: Elsevier), 111-165.

Stevens, Guy V. G. and Robert Lipsey (1992). "Interactions Between Domestic and Foreign Investment.” Journal of International Money and Finance 11:1, 40-62.

Stock, James H., and Mark W. Watson (2003). "Understanding Changes in International Business Cycle Dynamics.” NBER Working Paper No. 9859.

Stockman, Alan C. (1988). "Sectoral and National Aggregate Disturbances to Industrial Output in Seven European Countries", Journal of Monetary Economics, 21:387-409.

World Bank (2003). World Development Indicators. The World Bank: Washington D.C. 
Figure 1: The Sectoral Composition of U.S. Multinational Affiliate Gross Product, 1982-- 1999

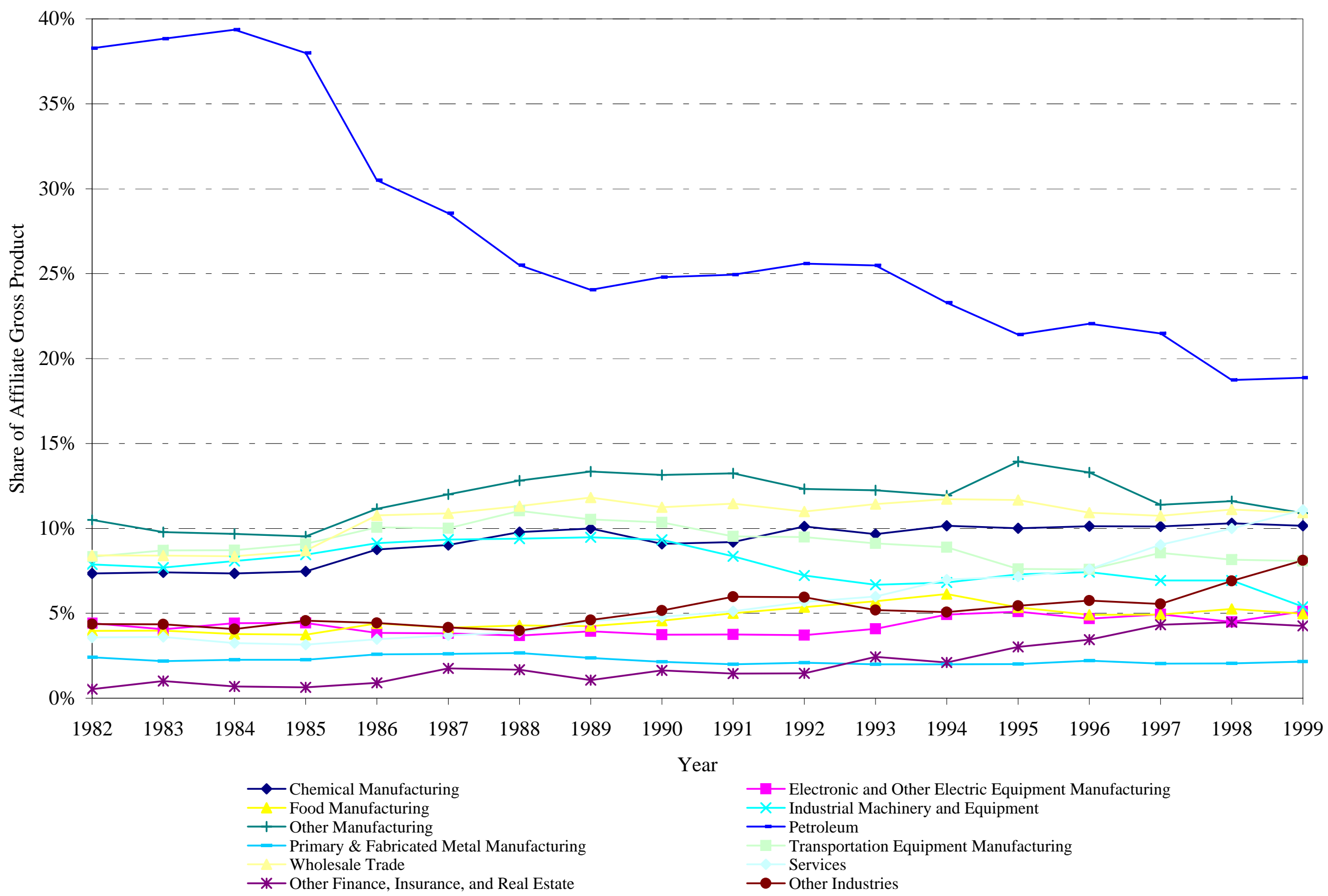

Note: The figure provides the share of worldwide U.S. multinational gross product by industry from 1982 to 1999. 
Table 1: The Distribution of Global Output and US Multinational Activity Around the World, 1982, 1989, 1994, and 1999

\begin{tabular}{|c|c|c|c|c|c|c|c|c|c|}
\hline & \multicolumn{2}{|c|}{$\underline{1982}$} & \multicolumn{2}{|c|}{$\underline{1989}$} & \multicolumn{2}{|c|}{$\underline{1994}$} & \multicolumn{2}{|c|}{$\underline{1999}$} \\
\hline & & $G D P$ & $M N C$ & $G D P$ & $M N C$ & $G D P$ & $M N C$ & $G D P$ & $M N C$ \\
\hline & & Share & Share & Share & Share & Share & Share & Share & Share \\
\hline \multicolumn{10}{|l|}{ Asia } \\
\hline & China & $2.81 \%$ & $0.00 \%$ & $2.64 \%$ & $0.00 \%$ & $2.83 \%$ & $0.17 \%$ & $4.68 \%$ & $0.70 \%$ \\
\hline & Hong Kong & $0.44 \%$ & $0.43 \%$ & $0.52 \%$ & $0.91 \%$ & $0.68 \%$ & $1.21 \%$ & $0.75 \%$ & $1.41 \%$ \\
\hline & India & $2.71 \%$ & $0.10 \%$ & $2.25 \%$ & $0.05 \%$ & $1.68 \%$ & $0.06 \%$ & $2.10 \%$ & $0.19 \%$ \\
\hline & Japan & $15.30 \%$ & $2.05 \%$ & $22.90 \%$ & $4.65 \%$ & $25.10 \%$ & $5.39 \%$ & $21.23 \%$ & $5.34 \%$ \\
\hline & Korea & $1.04 \%$ & $0.10 \%$ & $1.70 \%$ & $0.23 \%$ & $2.10 \%$ & $0.36 \%$ & $1.92 \%$ & $0.58 \%$ \\
\hline & Singapore & $0.21 \%$ & $0.50 \%$ & $0.23 \%$ & $0.73 \%$ & $0.36 \%$ & $1.42 \%$ & $0.39 \%$ & $1.74 \%$ \\
\hline & Taiwan & $0.68 \%$ & $0.28 \%$ & $1.15 \%$ & $0.60 \%$ & $1.27 \%$ & $0.70 \%$ & $1.36 \%$ & $1.07 \%$ \\
\hline \multicolumn{10}{|c|}{ Europe } \\
\hline & Belgium & $1.23 \%$ & $2.29 \%$ & $1.22 \%$ & $2.66 \%$ & $1.23 \%$ & $2.92 \%$ & $1.19 \%$ & $2.33 \%$ \\
\hline & France & $7.84 \%$ & $5.44 \%$ & $7.58 \%$ & $7.02 \%$ & $7.05 \%$ & $7.87 \%$ & $6.82 \%$ & $6.62 \%$ \\
\hline & Germany & $10.50 \%$ & $11.07 \%$ & $10.49 \%$ & $11.12 \%$ & $10.91 \%$ & $13.68 \%$ & $9.94 \%$ & $10.93 \%$ \\
\hline & Ireland & $0.29 \%$ & $0.85 \%$ & $0.29 \%$ & $1.39 \%$ & $0.29 \%$ & $1.57 \%$ & $0.45 \%$ & $2.62 \%$ \\
\hline & Italy & $5.59 \%$ & $3.79 \%$ & $6.73 \%$ & $5.14 \%$ & $5.35 \%$ & $4.62 \%$ & $5.58 \%$ & $3.96 \%$ \\
\hline & Netherlands & $2.01 \%$ & $2.41 \%$ & $1.83 \%$ & $4.12 \%$ & $1.82 \%$ & $3.61 \%$ & $1.88 \%$ & $3.36 \%$ \\
\hline & Norway & $0.85 \%$ & $1.98 \%$ & $0.76 \%$ & $1.30 \%$ & $0.64 \%$ & $1.12 \%$ & $0.73 \%$ & $1.11 \%$ \\
\hline & Spain & $2.59 \%$ & $1.15 \%$ & $3.04 \%$ & $2.30 \%$ & $2.63 \%$ & $2.00 \%$ & $2.85 \%$ & $1.90 \%$ \\
\hline & Sweden & $1.44 \%$ & $0.84 \%$ & $1.53 \%$ & $0.69 \%$ & $1.08 \%$ & $0.63 \%$ & $1.15 \%$ & $1.09 \%$ \\
\hline & Switzerland & $1.39 \%$ & $1.43 \%$ & $1.38 \%$ & $1.59 \%$ & $1.36 \%$ & $1.75 \%$ & $1.22 \%$ & $1.58 \%$ \\
\hline & United Kingdom & $6.73 \%$ & $17.19 \%$ & $6.49 \%$ & $16.42 \%$ & $5.44 \%$ & $15.55 \%$ & $6.89 \%$ & $18.19 \%$ \\
\hline \multicolumn{10}{|c|}{ North America } \\
\hline & Canada & $4.22 \%$ & $15.21 \%$ & $4.22 \%$ & $16.24 \%$ & $2.90 \%$ & $11.87 \%$ & $3.07 \%$ & $11.61 \%$ \\
\hline & Mexico & $2.42 \%$ & $1.59 \%$ & $1.72 \%$ & $1.52 \%$ & $2.19 \%$ & $2.44 \%$ & $2.27 \%$ & $3.10 \%$ \\
\hline \multicolumn{10}{|c|}{ Oceania } \\
\hline & Australia & $2.54 \%$ & $4.50 \%$ & $2.35 \%$ & $4.33 \%$ & $1.80 \%$ & $3.72 \%$ & $1.92 \%$ & $3.46 \%$ \\
\hline \multicolumn{10}{|c|}{ South America } \\
\hline & Argentina & $1.17 \%$ & $1.30 \%$ & $0.59 \%$ & $0.49 \%$ & $1.34 \%$ & $1.05 \%$ & $1.34 \%$ & $1.28 \%$ \\
\hline & Brazil & $3.92 \%$ & $5.01 \%$ & $3.46 \%$ & $5.49 \%$ & $2.85 \%$ & $4.17 \%$ & $2.51 \%$ & $2.93 \%$ \\
\hline & Total & $77.92 \%$ & $79.50 \%$ & $85.09 \%$ & $89.00 \%$ & $82.90 \%$ & $87.87 \%$ & $82.22 \%$ & $87.12 \%$ \\
\hline
\end{tabular}

Note: The table provides information on the distribtuion of GDP and U.S. multinational gross product across countries in 1982, 1989, 1994 and 1999. GDP Share is the ratio of individual country GDP to total non-U.S. GDP. MNC Share is the ratio total U.S. multinational gross product in a country to the gross product of U.S. multinational affiliates worldwide. The table is restricted to those countries that, in 1999, comprise either one percent of non-U.S. world output or one percent of U.S. multinational gross product. 
Table 2: The Scope of U.S. Multinational Activity, 1982-1999 and 1999

Average Ratio of U.S.

MNC Capital

Average Ratio of U.S. Ratio of U.S. MNC MNC Gross Product Gross Product to to GDP, 1982-1999
Expenditures to Gross Cat Fixed Capital Formation, 1982-1999
Ratio of U.S. MNC Capital Expenditures to Gross Fixed Capital

Formation, 1999

Asia

China

Hong Kong

India

Japan

Korea

Singapore

Taiwan

Europe

Belgium

France

Germany

Ireland

Italy

Netherlands

Norway

Spain

Sweden

Switzerland

United Kingdom
$0.10 \%$

$3.93 \%$

$0.10 \%$

$0.49 \%$

$0.38 \%$

$8.43 \%$

$1.23 \%$

$5.26 \%$

$2.31 \%$

$2.82 \%$

$12.00 \%$

$1.86 \%$

$4.49 \%$

$4.85 \%$

$1.64 \%$

$1.52 \%$

$2.86 \%$

$6.72 \%$
$0.40 \%$

$5.06 \%$

$0.24 \%$

$0.67 \%$

$0.81 \%$

$11.92 \%$

$2.11 \%$
$0.24 \%$

$3.35 \%$

$0.14 \%$

$0.21 \%$

$0.26 \%$

$5.08 \%$

NA
$0.45 \%$

$3.28 \%$

$0.37 \%$

$0.32 \%$

$0.41 \%$

$7.57 \%$

NA

North America
Canada
Mexico

$9.47 \%$

$10.12 \%$

$3.21 \%$

$2.74 \%$

$2.42 \%$

$3.65 \%$

$1.47 \%$

$1.56 \%$

$1.59 \%$

$1.79 \%$

$15.65 \%$

$7.64 \%$

$9.69 \%$

$1.90 \%$

$0.85 \%$

$0.99 \%$

$4.78 \%$

$3.38 \%$

$3.25 \%$

$4.10 \%$

$5.27 \%$

$4.40 \%$

$1.79 \%$

$1.23 \%$

$1.23 \%$

$2.55 \%$

$1.12 \%$

$2.17 \%$

$3.46 \%$

$1.15 \%$

$2.10 \%$

$7.07 \%$

$6.80 \%$

$8.47 \%$

$11.16 \%$

$4.15 \%$

Oceania

Australia

$4.53 \%$

$4.83 \%$

$3.46 \%$

$5.35 \%$

South America

Argentina

$2.22 \%$

$2.56 \%$

$2.47 \%$

$3.92 \%$

Brazil

$3.12 \%$

$2.49 \%$

$3.51 \%$

Note: The table provides the ratio of U.S. multinational gross product (capital expenditure) to country GDP (gross fixed capital formation), by country, averaged from 1982 to 1999 and 1999. The table is restricted to those countries that, in 1999, comprise either one percent of non-U.S. world output or one percent of U.S. multinational gross product. 


\section{Table 3: Descriptive Statistics}

Mean Median Standard Deviation

Correlation Tables

Multinational Measures

ROR
0.1894
0.1864
0.0929
0.1308
0.1275
0.0440
0.0399
0.0392
0.0158

ROE

$\mathrm{ROA}$

Capital Expenditures

$5,266,974$

$4,057,498$

4,464,127

0.1383

0.1311

0.0391

Capital Expenditures/Assets

0.0466

0.0449

0.0178

Local Firm Measures

ROR

ROE

Stock Returns

0.1118

0.1151

0.0337

0.1623

0.1514

0.3129

Capital Expenditures

$322,000,000,000$

$203,000,000,000$

$328,000,000,000$

Capital Expenditures/Gross Product

0.2156

0.2089

0.0380

Regression Tables

Affiliate ROE

Parent ROE

Other Affiliate ROE

Host Country ROE

Log of Affiliate Capital Expenditures

Log of Parent Capital Expenditures

Log of Other Affiliate Capital Expenditures

Log of Host Country Gross Fixed Capital

Formation

Affiliate Capital Expenditures/Assets

Parent Capital Expenditures/Assets

Other Affiliate Capital Expenditures/Assets

Host Country Gross Fixed Capital

Formation/GDP
0.1586

0.1202

0.1381

0.1201

6.3604

11.7526

10.6546

24.9104

0.0504

0.0518

0.0457

0.2187
0.1285

0.1273

0.1284

0.1197

6.5221

11.9585

10.8314

25.1231

0.0161

0.0439

0.0345

0.2095
0.3797

0.2290

0.1958

0.0340

2.4253

2.1054

2.5011

1.5006

0.1108

0.0480

0.0542

0.0487

Note: The two panels of the table provide descriptive statistics for the correlation tables and regression tables, respectively. Each of the Multinational Measures in the correlation tables relates to measures for the G-8 (excluding Russia and the U.S.) and are based on the activities of U.S. multinationals from 1982 to 1999 as described in the text. Local Firm Measures relate to measures for the G-8 (excluding Russia and the U.S.) and are drawn from Poterba (1999), Ken French's website (http://mba.tuck.dartmouth.edu/pages/faculty/ken.french/) and the World Bank Development Indicators as described in the text. "Affiliate," "Parent" and "Other Affiliate" variables are associated with a multinational affiliate, their parent's domestic activity, and their parent's other foreign operations, respectively. "Host country" refers to the country of activity for the multinational activity and that data is drawn from the Ken French website (for ROEs) and World Bank Development Indicators (for gross fixed capital formation). 
Table 4: The Correlation of Returns for U.S. Multinationals and Local Firms, 1982-1999

U.S. Multinational Firms

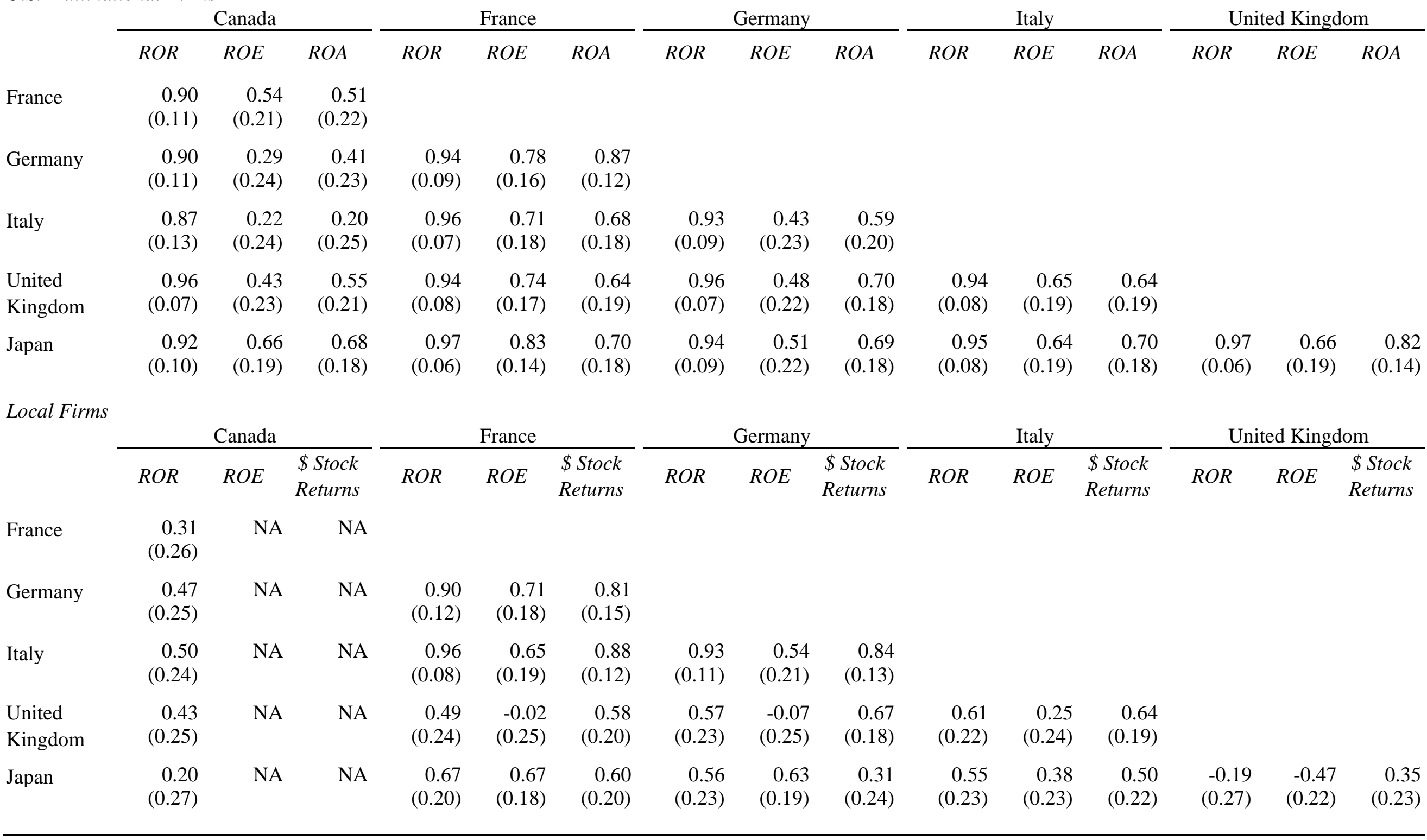

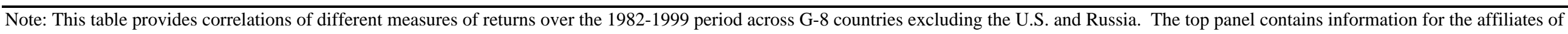

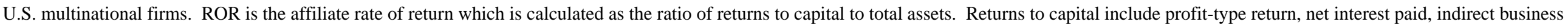

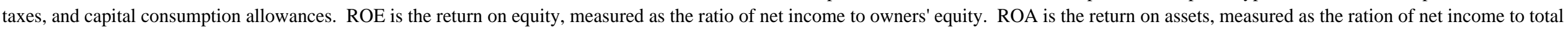

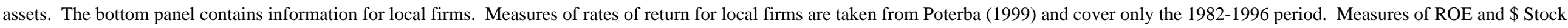
Returns for local firms are taken from the Ken French website. Standard error appear below each correlation coefficient in parentheses. 
Table 5: The Correlation of Investment Rates for U.S. Multinationals and Local Firms, 1982-1999

U.S. Multinational Firms

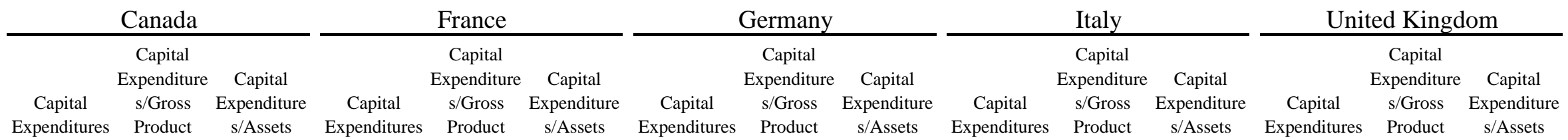

\begin{tabular}{|c|c|c|c|c|c|c|c|c|c|c|c|c|c|c|c|}
\hline France & $\begin{array}{r}0.77 \\
(0.16)\end{array}$ & $\begin{array}{r}-0.40 \\
(0.23)\end{array}$ & $\begin{array}{r}0.66 \\
(0.19)\end{array}$ & & & & & & & & & & & & \\
\hline Germany & $\begin{array}{r}0.87 \\
(0.12)\end{array}$ & $\begin{array}{r}0.29 \\
(0.24)\end{array}$ & $\begin{array}{r}0.68 \\
(0.18)\end{array}$ & $\begin{array}{r}0.92 \\
(0.10)\end{array}$ & $\begin{array}{r}0.22 \\
(0.24)\end{array}$ & $\begin{array}{r}0.95 \\
(0.08)\end{array}$ & & & & & & & & & \\
\hline Italy & $\begin{array}{r}0.85 \\
(0.13)\end{array}$ & $\begin{array}{r}0.47 \\
(0.22)\end{array}$ & $\begin{array}{r}0.76 \\
(0.16)\end{array}$ & $\begin{array}{r}0.94 \\
(0.09)\end{array}$ & $\begin{array}{r}0.29 \\
(0.24)\end{array}$ & $\begin{array}{r}0.89 \\
(0.11)\end{array}$ & $\begin{array}{r}0.95 \\
(0.08)\end{array}$ & $\begin{array}{r}0.39 \\
(0.23)\end{array}$ & $\begin{array}{r}0.89 \\
(0.11)\end{array}$ & & & & & & \\
\hline $\begin{array}{l}\text { United } \\
\text { Kingdom }\end{array}$ & $\begin{array}{r}0.89 \\
(0.12)\end{array}$ & $\begin{array}{r}0.06 \\
(0.25)\end{array}$ & $\begin{array}{r}0.85 \\
(0.13)\end{array}$ & $\begin{array}{r}0.83 \\
(0.14)\end{array}$ & $\begin{array}{r}0.60 \\
(0.20)\end{array}$ & $\begin{array}{r}0.90 \\
(0.11)\end{array}$ & $\begin{array}{r}0.92 \\
(0.10)\end{array}$ & $\begin{array}{r}0.57 \\
(0.21)\end{array}$ & $\begin{array}{r}0.90 \\
(0.11)\end{array}$ & $\begin{array}{r}0.90 \\
(0.11)\end{array}$ & $\begin{array}{r}0.50 \\
(0.22)\end{array}$ & $\begin{array}{r}0.94 \\
(0.08)\end{array}$ & & & \\
\hline Japan & $\begin{array}{r}0.93 \\
(0.09)\end{array}$ & $\begin{array}{r}0.34 \\
(0.24)\end{array}$ & $\begin{array}{r}0.80 \\
(0.15)\end{array}$ & $\begin{array}{r}0.89 \\
(0.11)\end{array}$ & $\begin{array}{r}0.37 \\
(0.23)\end{array}$ & $\begin{array}{r}0.92 \\
(0.10)\end{array}$ & $\begin{array}{r}0.94 \\
(0.08)\end{array}$ & $\begin{array}{r}0.55 \\
(0.21)\end{array}$ & $\begin{array}{r}0.93 \\
(0.09)\end{array}$ & $\begin{array}{r}0.91 \\
(0.10)\end{array}$ & $\begin{array}{r}0.38 \\
(0.23)\end{array}$ & $\begin{array}{r}0.91 \\
(0.10)\end{array}$ & $\begin{array}{r}0.88 \\
(0.12)\end{array}$ & $\begin{array}{r}0.25 \\
(0.24)\end{array}$ & $\begin{array}{r}0.93 \\
(0.09)\end{array}$ \\
\hline
\end{tabular}

Local Firms

Canada

$\begin{array}{cc}\begin{array}{c}\text { Capital } \\ \text { Expenditures }\end{array} & \begin{array}{c}\text { Expenditures/C } \\ \text { Product }\end{array} \\ 0.88 & 0.72 \\ (0.12) & (0.17)\end{array}$

France

\begin{tabular}{cc}
\hline & Capital \\
Capital & Expenditures/Gross \\
Expenditures & Product
\end{tabular}

Germany

$\begin{array}{cc} & \text { Capital } \\ \text { Capital } & \text { Expenditures/Gross } \\ \text { Expenditures } & \text { Product }\end{array}$

Italy

\begin{tabular}{cc}
\hline & Capital \\
Capital & Expenditures/Gross \\
Expenditures & Product
\end{tabular}

United Kingdom

$\begin{array}{cc} & \text { Capital } \\ \text { Capital } & \text { Expenditures/Gross } \\ \text { Expenditures } & \text { Product }\end{array}$

France

Germany

$$
\begin{array}{r}
0.76 \\
(0.16)
\end{array}
$$$$
-0.59
$$$$
\text { (0.20) }
$$

0.96

$-0.13$

(0.07)

(0.25)

Italy

$$
\begin{array}{r}
0.91 \\
(0.11)
\end{array}
$$

0.67

0.96

0.83

(0.07)
(0.14)

0.87

$-0.44$

0.95

0.74

(0.12)

(0.22)

Kingdom

(0.15)

$(0.24)$

(0.08)

(0.17)

$\begin{array}{rc}0.98 & 0.39 \\ (0.06) & (0.23)\end{array}$

\begin{tabular}{rc}
0.86 & 0.36 \\
$(0.13)$ & $(0.23)$ \\
0.90 & 0.49 \\
$(0.11)$ & $(0.22)$ \\
\hline
\end{tabular}

(0.11)

0.68

0.82

$-0.45$

(0.14)

$(0.22)$

(0.11)

(0.22)

0.81

0.48

$(0.15) \quad(0.22)$

Note:This table provides correlations of different measures of investment activity over the 1982-1999 period across G-8 countries excluding the U.S. and Russia. The top panel contains information for the affiliates of U.S. multinational firms. Capital Expenditures is the log of affiliate capital expenditures and capital expenditures/gross product is the ratio of affiliate capital expenditures to affiliate gross product. Capital expenditures/assets is the ratio of affiliate capital expenditures to affiliate assets. The bottom panel contains information for local firms. Gross fixed capital formation data from the World Banks are used to measure country investment and the log of these expenditures and these expenditures scaled by country GDP are used as measures of capital expenditures and capital expenditures/gross product. Standard error appear below each correlation coefficient in parentheses. 
Table 6

\section{The Interrelationship of Returns Within Multinational Firms}

Affiliate ROE

\begin{tabular}{|c|c|c|c|c|c|c|c|}
\hline & \multicolumn{3}{|c|}{ Full Sample } & \multicolumn{4}{|c|}{ G-6 } \\
\hline & (1) & (2) & (3) & (4) & (5) & (6) & (7) \\
\hline Constant & $\begin{array}{r}0.1638 \\
(0.0063)\end{array}$ & $\begin{array}{r}0.1458 \\
(0.0068)\end{array}$ & $\begin{array}{r}0.1584 \\
(0.0134)\end{array}$ & $\begin{array}{r}0.1062 \\
(0.0083)\end{array}$ & $\begin{array}{r}0.1514 \\
(0.0082)\end{array}$ & $\begin{array}{r}0.1320 \\
(0.0166)\end{array}$ & $\begin{array}{r}0.1975 \\
(0.0653)\end{array}$ \\
\hline Parent ROE & $\begin{array}{r}0.0878 \\
(0.0111)\end{array}$ & $\begin{array}{r}0.0679 \\
(0.0102)\end{array}$ & $\begin{array}{r}0.0671 \\
(0.0135)\end{array}$ & $\begin{array}{r}0.0887 \\
(0.0134)\end{array}$ & $\begin{array}{r}0.0662 \\
(0.0135)\end{array}$ & $\begin{array}{r}0.0668 \\
(0.0165)\end{array}$ & $\begin{array}{r}0.0620 \\
(0.0133)\end{array}$ \\
\hline Other Affiliate ROE & & $\begin{array}{r}0.1400 \\
(0.0144)\end{array}$ & $\begin{array}{r}0.1619 \\
(0.0192)\end{array}$ & & $\begin{array}{r}0.1318 \\
(0.0161)\end{array}$ & $\begin{array}{r}0.1598 \\
(0.0214)\end{array}$ & $\begin{array}{r}0.1256 \\
(0.0158)\end{array}$ \\
\hline Host Country ROE & & & $\begin{array}{r}0.0465 \\
(0.0817)\end{array}$ & & & $\begin{array}{r}0.1563 \\
(0.1314)\end{array}$ & \\
\hline $\begin{array}{l}\text { Affiliate and Year Fixed } \\
\text { Effects? }\end{array}$ & $\mathrm{Y}$ & $\mathrm{Y}$ & $\mathrm{Y}$ & $\mathrm{Y}$ & $\mathrm{Y}$ & $\mathrm{Y}$ & $\mathrm{N}$ \\
\hline $\begin{array}{l}\text { Affiliate, Country/Year, and } \\
\text { Industry/Year Fixed Effects? }\end{array}$ & $\mathrm{N}$ & $\mathrm{N}$ & $\mathrm{N}$ & $\mathrm{N}$ & $\mathrm{N}$ & $\mathrm{N}$ & $\mathrm{Y}$ \\
\hline No. of Obs. & 178,980 & 170,634 & 99,696 & 76,372 & 70,892 & 54,141 & 70,892 \\
\hline R-Squared & 0.5156 & 0.5184 & 0.5064 & 0.4981 & 0.5014 & 0.5027 & 0.5063 \\
\hline
\end{tabular}

Note: The dependent variable in these specifications is affiliate ROE defined as the ratio of net income to owner's equity. The specifications in columns in 4 through 7 are restricted to affiliates in G-6 countries. The specifications in columns 1 through 6 and 8 employ affiliate and year fixed effects. The specification in column 7 employs affiliate, country/year and industry/year fixed effects. "Parent ROE" is the ratio of net income to owner's equity of the affiliate's parent in the U.S. "Other Affiliate ROE" is the ratio of net income to owner's equity of the other foreign affiliates of the affiliate's parent. "Host Country ROE" is the return on equity for local firms taken from the Ken French website. Standard errors are clustered at the affiliate level. 
Table 7

The Interrelationship of Capital Expenditures Within Multinational Firms

\begin{tabular}{|c|c|c|c|c|c|c|c|c|c|c|c|c|c|c|}
\hline \multirow[t]{3}{*}{ Dependent Variable: } & \multicolumn{7}{|c|}{ Log Affiliate Capital Exenditure } & \multicolumn{7}{|c|}{ Affiliate Capital Expenditure/Assets } \\
\hline & \multicolumn{3}{|c|}{ All countries } & \multicolumn{4}{|c|}{ G-6 } & \multicolumn{3}{|c|}{ All countries } & \multicolumn{4}{|c|}{ G-6 } \\
\hline & (1) & $(2)$ & (3) & (4) & (5) & (6) & (7) & (8) & (9) & $(10)$ & (11) & $(12)$ & (13) & (14) \\
\hline Constant & $\begin{array}{r}3.7416 \\
(0.2156)\end{array}$ & $\begin{array}{r}2.6550 \\
(0.2524)\end{array}$ & $\begin{array}{c}-12.5957 \\
(1.1998)\end{array}$ & $\begin{array}{r}3.6315 \\
(0.2128)\end{array}$ & $\begin{array}{r}2.9509 \\
(0.2597)\end{array}$ & $\begin{array}{r}-17.1811 \\
(2.4016)\end{array}$ & $\begin{array}{r}2.4224 \\
(0.4886)\end{array}$ & $\begin{array}{r}0.0505 \\
(0.0022)\end{array}$ & $\begin{array}{r}0.0380 \\
(0.0031)\end{array}$ & $\begin{array}{r}0.0264 \\
(0.0051)\end{array}$ & $\begin{array}{r}0.0289 \\
(0.0020)\end{array}$ & $\begin{array}{r}0.0196 \\
(0.0025)\end{array}$ & $\begin{array}{r}0.0177 \\
(0.0075)\end{array}$ & $\begin{array}{r}0.1631 \\
(0.0213)\end{array}$ \\
\hline $\begin{array}{l}\text { Log of Parent Capital } \\
\text { Exenditure }\end{array}$ & $\begin{array}{r}0.2043 \\
(0.0190)\end{array}$ & $\begin{array}{r}0.1445 \\
(0.0161)\end{array}$ & $\begin{array}{r}0.1385 \\
(0.0154)\end{array}$ & $\begin{array}{r}0.2102 \\
(0.0194)\end{array}$ & $\begin{array}{r}0.1574 \\
(0.0188)\end{array}$ & $\begin{array}{r}0.1564 \\
(0.0186)\end{array}$ & $\begin{array}{r}0.1455 \\
(0.0186)\end{array}$ & & & & & & & \\
\hline $\begin{array}{l}\text { Log of Other Affiliate } \\
\text { Capital Expenditure }\end{array}$ & & $\begin{array}{r}0.2106 \\
(0.0155)\end{array}$ & $\begin{array}{c}0.2071 \\
(0.0151)\end{array}$ & & $\begin{array}{r}0.1902 \\
(0.0164)\end{array}$ & $\begin{array}{r}0.1898 \\
(0.0164)\end{array}$ & $\begin{array}{r}0.1848 \\
(0.0166)\end{array}$ & & & & & & & \\
\hline $\begin{array}{l}\text { Log of Host Country Gross } \\
\text { Fixed Capital Formation }\end{array}$ & & & $\begin{array}{r}0.6104 \\
(0.0465)\end{array}$ & & & $\begin{array}{r}0.7582 \\
(0.0906)\end{array}$ & & & & & & & & \\
\hline $\begin{array}{l}\text { Parent Capital } \\
\text { Exenditure/Assets }\end{array}$ & & & & & & & & $\begin{array}{r}0.1455 \\
(0.0273)\end{array}$ & $\begin{array}{r}0.0961 \\
(0.0208)\end{array}$ & $\begin{array}{r}0.0991 \\
(0.0217)\end{array}$ & $\begin{array}{r}0.1177 \\
(0.0261)\end{array}$ & $\begin{array}{r}0.0842 \\
(0.0216)\end{array}$ & $\begin{array}{r}0.0842 \\
(0.0216)\end{array}$ & $\begin{array}{r}0.0809 \\
(0.0211)\end{array}$ \\
\hline $\begin{array}{l}\text { Host Country Gross Fixed } \\
\text { Capital Formation/GDP }\end{array}$ & & & & & & & & & & $\begin{array}{r}0.0362 \\
(0.0201)\end{array}$ & & & $\begin{array}{r}0.0096 \\
(0.0359)\end{array}$ & \\
\hline $\begin{array}{l}\text { Affiliate and Year Fixed } \\
\text { Effects? }\end{array}$ & $\mathrm{Y}$ & $\mathrm{Y}$ & $\mathrm{Y}$ & $\mathrm{Y}$ & $\mathrm{Y}$ & $\mathrm{Y}$ & $\mathrm{N}$ & $\mathrm{Y}$ & $\mathrm{Y}$ & $\mathrm{Y}$ & $\mathrm{Y}$ & $\mathrm{Y}$ & $\mathrm{Y}$ & $\mathrm{N}$ \\
\hline $\begin{array}{l}\text { Affiliate, Country/Year, } \\
\text { and Industry/Year Fixed } \\
\text { Effects? }\end{array}$ & $\mathrm{N}$ & $\mathrm{N}$ & $\mathrm{N}$ & $\mathrm{N}$ & $\mathrm{N}$ & $\mathrm{N}$ & $\mathrm{Y}$ & $\mathrm{N}$ & $\mathrm{N}$ & $\mathrm{N}$ & $\mathrm{N}$ & $\mathrm{N}$ & $\mathrm{N}$ & $\mathrm{Y}$ \\
\hline No. of Obs. & 161,034 & 153,022 & 146,262 & 71,325 & 65,691 & 65,691 & 65,687 & 210,132 & 201,042 & 186,693 & 89,201 & 83,227 & 83,227 & 83,227 \\
\hline R-Squared & 0.7867 & 0.7906 & 0.7894 & 0.7950 & 0.8008 & 0.8018 & 0.8075 & 0.5867 & 0.5946 & 0.5940 & 0.5673 & 0.5780 & 0.5780 & 0.5829 \\
\hline
\end{tabular}

Note: The dependent variable in the specifications presented in columns 1 through 7 is the log of affiliate capital expenditures. The dependent variable in the specifications presented in columns 8 through 14 is the ratio of affiliate capital expenditures to affiliate assets. The specifications in columns in 4 through 7 and 11 through 14 are restricted to affiliates in G-6 countries. The specifications in columns 1 through 6 and 8 through 13 employ affiliate and year fixed effects. The specifications in columns 7 and 14 employ affiliate, country/year and industry/year fixed effects. "Log of Parent Capital Expenditures" is the log of capital expenditures of the affiliates parent in the U.S. "Log of Other Affiliate Capital Expenditure" is the log of capital expenditures of other foreign affiliates of the affiliate's parent. "Log of Host Country Fixed Capital Formation" is the log of gross fixed capital formation in the country of the affiliate. "Parent Capital Expenditure/Assets" is the ratio of the capital expenditure of an affiliate's parent in the U.S. to their U.S. assets. "Other Affiliate Capital Expenditure/Assets" is the ratio of the capital expenditure of an affiliate's parent abroad to their foreign assets. "Host Country Gross Fixed Capital Formation/GDP" is the ratio of gross fixed capital formation to GDP in the country of the affilaite. Standard errors are clustered at the affiliate level. 
Table 8

Industry Factors, Trade Linkages, and the Interrelationship of Returns and Capital Expenditures

\begin{tabular}{|c|c|c|c|c|c|c|c|c|c|}
\hline \multirow[t]{3}{*}{ Dependent Variable: } & \multicolumn{4}{|c|}{ Affiliate ROE } & & \multicolumn{4}{|c|}{ Affiliate Capital Expenditure/Assets } \\
\hline & \multicolumn{2}{|c|}{ All Countries } & \multicolumn{2}{|c|}{ G-6 } & & \multicolumn{2}{|c|}{ All Countries } & \multicolumn{2}{|c|}{ G-6 } \\
\hline & (1) & (2) & (3) & (4) & & (5) & (6) & (7) & (8) \\
\hline Constant & $\begin{array}{r}0.1589 \\
(0.0136)\end{array}$ & $\begin{array}{r}0.1597 \\
(0.0130)\end{array}$ & $\begin{array}{r}0.1238 \\
(0.0771)\end{array}$ & $\begin{array}{r}0.1171 \\
(0.0717)\end{array}$ & Constant & $\begin{array}{r}0.0254 \\
(0.0050)\end{array}$ & $\begin{array}{r}0.0280 \\
(0.0052)\end{array}$ & $\begin{array}{r}0.1781 \\
(0.0169)\end{array}$ & $\begin{array}{r}-0.3292 \\
(0.0105)\end{array}$ \\
\hline Parent ROE & $\begin{array}{r}0.0626 \\
(0.0189)\end{array}$ & $\begin{array}{r}0.0712 \\
(0.0158)\end{array}$ & $\begin{array}{r}0.0473 \\
(0.0190)\end{array}$ & $\begin{array}{r}0.0604 \\
(0.0167)\end{array}$ & Parent CapEx/Assets & $\begin{array}{r}0.1370 \\
(0.0230)\end{array}$ & $\begin{array}{r}0.1006 \\
(0.0193)\end{array}$ & $\begin{array}{r}0.1292 \\
(0.0250)\end{array}$ & $\begin{array}{r}0.0935 \\
(0.0161)\end{array}$ \\
\hline $\begin{array}{l}\text { Parent ROE * Non } \\
\text { Manufacturing Dummy }\end{array}$ & $\begin{array}{r}0.0072 \\
(0.0230)\end{array}$ & & $\begin{array}{r}0.0330 \\
(0.0262)\end{array}$ & & $\begin{array}{l}\text { Parent CapEx/Assets * Non } \\
\text { Manufacturing Dummy }\end{array}$ & $\begin{array}{r}-0.0584 \\
(0.0385)\end{array}$ & & $\begin{array}{r}-0.0748 \\
(0.0402)\end{array}$ & \\
\hline Parent ROE * Local Sales Focus & & $\begin{array}{r}-0.0232 \\
(0.0254)\end{array}$ & & $\begin{array}{r}-0.0001 \\
(0.0271)\end{array}$ & $\begin{array}{l}\text { Parent CapEx/Assets * Local } \\
\text { Sales Focus Dummy }\end{array}$ & & $\begin{array}{r}0.0088 \\
(0.0529)\end{array}$ & & $\begin{array}{r}-0.0228 \\
(0.0636)\end{array}$ \\
\hline Other Affiliate ROE & $\begin{array}{r}0.1650 \\
(0.0249)\end{array}$ & $\begin{array}{r}0.1760 \\
(0.0205)\end{array}$ & $\begin{array}{r}0.1142 \\
(0.0211)\end{array}$ & $\begin{array}{r}0.1340 \\
(0.0188)\end{array}$ & Other Affiliate CapEx/Assets & $\begin{array}{r}0.2577 \\
(0.0307)\end{array}$ & $\begin{array}{r}0.2507 \\
(0.0374)\end{array}$ & $\begin{array}{r}0.2078 \\
(0.0384)\end{array}$ & $\begin{array}{r}0.2406 \\
(0.0435)\end{array}$ \\
\hline $\begin{array}{l}\text { Other Affiliate ROE * Non } \\
\text { Manufacturing Dummy }\end{array}$ & $\begin{array}{r}-0.0034 \\
(0.0339)\end{array}$ & & $\begin{array}{r}0.0148 \\
(0.0299)\end{array}$ & & $\begin{array}{l}\text { Other Affiliate CapEx/Assets } \\
\text { * Non Manufacturing Dummy }\end{array}$ & $\begin{array}{r}0.0705 \\
(0.0651)\end{array}$ & & $\begin{array}{r}0.1021 \\
(0.0795)\end{array}$ & \\
\hline $\begin{array}{l}\text { Other Affiliate ROE * Local } \\
\text { Sales Focus Dummy }\end{array}$ & & $\begin{array}{r}-0.0591 \\
(0.0362)\end{array}$ & & $\begin{array}{r}-0.0381 \\
(0.0304)\end{array}$ & $\begin{array}{l}\text { Other Affiliate CapEx/Assets } \\
\text { * Local Sales Focus Dummy }\end{array}$ & & $\begin{array}{r}0.2091 \\
(0.1125)\end{array}$ & & $\begin{array}{r}0.1340 \\
(0.1341)\end{array}$ \\
\hline $\begin{array}{l}\text { Affiliate and Year Fixed Effects? } \\
\text { Affiliate, Country/Year, and }\end{array}$ & $\mathrm{Y}$ & $\mathrm{Y}$ & $\mathrm{N}$ & $\mathrm{N}$ & & $\mathrm{Y}$ & $\mathrm{Y}$ & $\mathrm{N}$ & $\mathrm{N}$ \\
\hline Industry/Year Fixed Effects? & $\mathrm{N}$ & $\mathrm{N}$ & $\mathrm{Y}$ & $\mathrm{Y}$ & & $\mathrm{N}$ & $\mathrm{N}$ & $\mathrm{Y}$ & $\mathrm{Y}$ \\
\hline No. of Obs. & 96,169 & 91,977 & 68,441 & 65,655 & & 180,167 & 171,904 & 80,244 & 77,215 \\
\hline R-Squared & 0.5056 & 0.4975 & 0.5044 & 0.4985 & & 0.5964 & 0.5722 & 0.5844 & 0.5642 \\
\hline
\end{tabular}

